\title{
Dinosaur-plant interactions within a Middle Jurassic ecosystem-palynology of the Burniston Bay dinosaur footprint locality, Yorkshire, UK
}

\author{
Sam M. Slater ${ }^{1,2} \cdot$ Charles H. Wellman $^{2} \cdot$ Michael Romano $^{3} \cdot$ Vivi Vajda $^{1}$
}

Received: 3 July 2017 /Revised: 18 September 2017 / Accepted: 25 October 2017 / Published online: 20 December 2017

(C) The Author(s) 2017. This article is an open access publication

\begin{abstract}
Dinosaur footprints are abundant in the Middle Jurassic Ravenscar Group of North Yorkshire, UK. Footprints are particularly common within the Bathonian Long Nab Member of the Scalby Formation and more so within the socalled 'Burniston footprint bed' at Burniston Bay. The Yorkshire Jurassic is also famous for its exceptional plant macrofossil and spore-pollen assemblages. Here we investigate the spore-pollen record from the dinosaur footprint-bearing successions in order to reconstruct the vegetation and assess possible dinosaur-plant interactions. We also compare the spore-pollen assemblages with the macroflora of the Scalby Ness Plant Bed, which occurs within the same geological member as the Burniston succession. The spore-pollen assemblages are dominated by Deltoidospora spp., the majority of which were probably produced by Coniopteris. Lycophyte spores (including megaspores) are common in the Yorkshire Jurassic, but lycophyte parent plants are extremely poorly represented in the macroflora. Seed ferns, represented by Alisporites spp., are moderately abundant. Conifer pollen assemblages are
\end{abstract}

This article is a contribution to the special issue "Jurassic biodiversity and terrestrial environments"

Electronic supplementary material The online version of this article (https://doi.org/10.1007/s12549-017-0309-9) contains supplementary material, which is available to authorized users.

Sam M. Slater

sam.slater@nrm.se

1 Department of Palaeobiology, Swedish Museum of Natural History, 10418 Stockholm, Sweden

2 Department of Animal and Plant Sciences, University of Sheffield, Alfred Denny Building, Western Bank, Sheffield S10 2TN, UK

314 Green Lane, Dronfield, Sheffield S18 2LZ, UK dominated by Araucariacites australis (probably produced by Brachyphyllum mamillare), Perinopollenites elatoides and Classopollis spp., with additional bisaccate pollen taxa. Abundant Ginkgo huttonii in the macroflora suggests that much of the monosulcate pollen was produced by ginkgoes. The diverse vegetation of the Cleveland Basin presumably represented an attractive food source for herbivorous dinosaurs. The dinosaurs probably gathered at the flood plains for fresh-water and also used the non-vegetated plains and coastline as pathways. Although assigning specific makers to footprints is difficult, it is clear that a range of theropod, ornithopod and sauropod dinosaurs inhabited the area.

Keywords Jurassic $\cdot$ Palynology $\cdot$ Spores and pollen · Dinosaur footprints · Yorkshire · Ravenscar Group · Scalby Formation

\section{Introduction}

The Jurassic (201-145 million years ago) represents an important period in the history of terrestrial ecosystems as it saw several major evolutionary developments, including diversification of the dinosaurs, appearance of the first birds and expansion of bennettite and ginkgophyte floras (e.g. Upchurch and Barrett 2005; Anderson et al. 2007; Slater et al. 2018, this issue). The Jurassic deposits of Yorkshire, UK (Fig. 1a), are famous for their well-preserved fossil assemblages, and the Middle Jurassic portion of the succession (Fig. 1b) represents an exceptional example of an extensive sequence of nonmarine deposits of this age. Plant macrofossils from this region are particularly well-preserved and have been studied extensively (e.g. Harris 1961, 1964, 1969, 1979; Harris et al. 1974; van Konijnenburg-van Cittert and Morgans 1999). The deposits also possess exquisite spore-pollen assemblages 
a

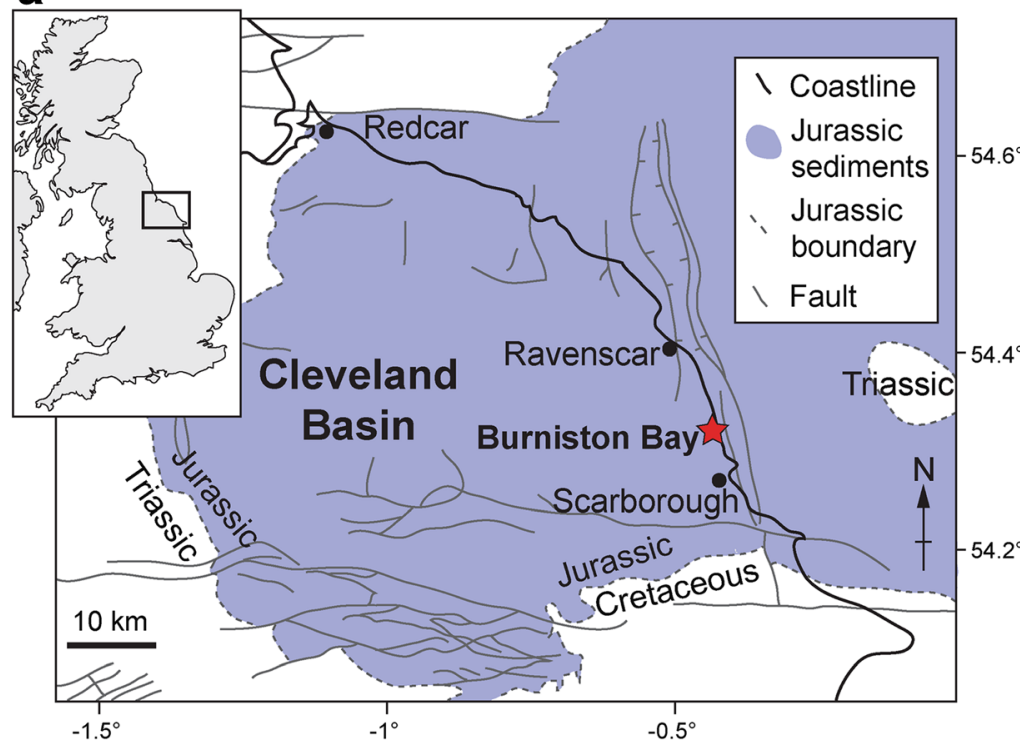

b

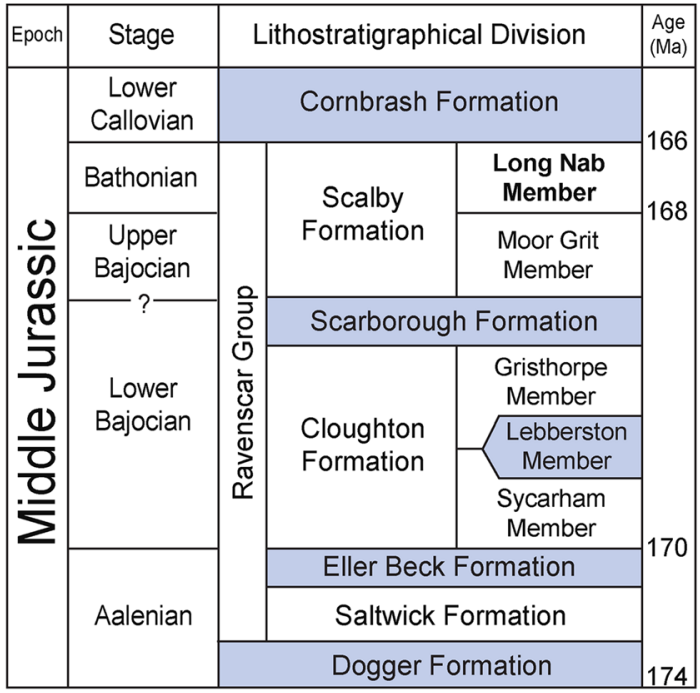

Fig. 1 Location (Burniston Bay) and stratigraphic position of the study section. a Geological map of the Cleveland Basin; modified from Milsom and Rawson (1989); Mjøs and Prestholm (1993); Palliani and Riding
(2000); Rawson and Wright (2000). b Subdivision of the Middle Jurassic of Yorkshire. Shaded units represent marine successions. Modified from Rawson and Wright (2000)
(Couper 1958; Chaloner 1968; Chaloner and Muir 1968; Boulter and Windle 1993; Srivastava 2011; Slater and Wellman 2015, 2016a, b), and the abundant dinosaur footprints (Romano and Whyte 2003) make this an important region from which a relatively complete Middle Jurassic terrestrial ecosystem reconstruction can be made.

Dinosaur bones from the Jurassic of Yorkshire are extremely rare (e.g. Whyte et al. 2010; Manning et al. 2015), however, dinosaur trace fossils are highly abundant and have been welldocumented since the early 1900s (e.g. Brodrick 1907; Hargreaves 1913, 1914). Based on the diversity and abundance of footprints, the Middle Jurassic of Yorkshire has been described as a 'megatracksite of global importance' (Romano and Whyte 2003). Although footprints are present throughout the Middle Jurassic of Yorkshire (selected traces shown in Fig. 3), dinosaur trace fossils are particularly common near the top of this succession from the deposits in and around Burniston Bay (Figs. 1 and 2). These sequences have yielded a wide range of track forms, including those of quadrupedal (sauropod, stegosaur) and bipedal (ornithopod, theropod) makers and possible swimming traces (Romano and Whyte 2003; Romano and Whyte 2015). The high diversity and abundance of footprints make the Burniston locality an ideal site to reconstruct the terrestrial ecosystem inhabited by the dinosaur fauna. Previous studies have shown that palynological analyses of specific beds hosting dinosaur remains or dinosaur tracks may provide a snapshot into the very ecosystems that the fauna inhabited during their lifetimes (Vajda et al. 2013a, b) and even, to some extent, the main food source of the local herbivores (Prasad et al. 2005; Vajda et al. 2016).

Most previous palynological investigations on the successions studied here have focussed on marine palynomorphs, e.g. dinoflagellate cysts (e.g. Fisher and Hancock 1985; Riding and Wright 1989). Here we examine the abundant and wellpreserved dispersed spore and pollen assemblages, comparing the palynological signal between the 'Burniston footprint bed' (see below) and the adjacent beds, with the aim to reconstruct the terrestrial ecosystem in which the Yorkshire dinosaurs thrived, and ultimately investigate possible dinosaur-plant interactions.

\section{Geological setting}

The study area is located in the Cleveland Basin on the North Yorkshire coast, UK (Fig. 1a). The Mesozoic sequences of this region have been intensively studied since the early nineteenth century for their geological, sedimentological and palaeontological significance (e.g. Young and Bird 1822). The Middle Jurassic portion of the Yorkshire coast succession comprises the predominantly non-marine deposits of the Ravenscar Group (Fig. 1b). These represent mostly paralic, fluvial and lacustrine successions deposited at a time of regional uplift and associated sea-level fall (Knox 1973; Hemingway and Knox 1973; Livera and Leeder 1981; Alexander 1989, 1992; Powell 2010).

The section under investigation is located in Burniston Bay (National grid reference TA 02827/93016) and is stratigraphically situated within the Long Nab Member of the Scalby Formation, at the top of the Ravenscar Group (Fig. 2). The Scalby Formation is the youngest non-marine formation within the Ravenscar Group and is bounded below and above by the marine Scarborough and Cornbrash formations, respectively (Fig. 1b). The Scalby Formation represents fluvio-deltaic conditions (Leeder and Nami 1979; Fisher and 
a

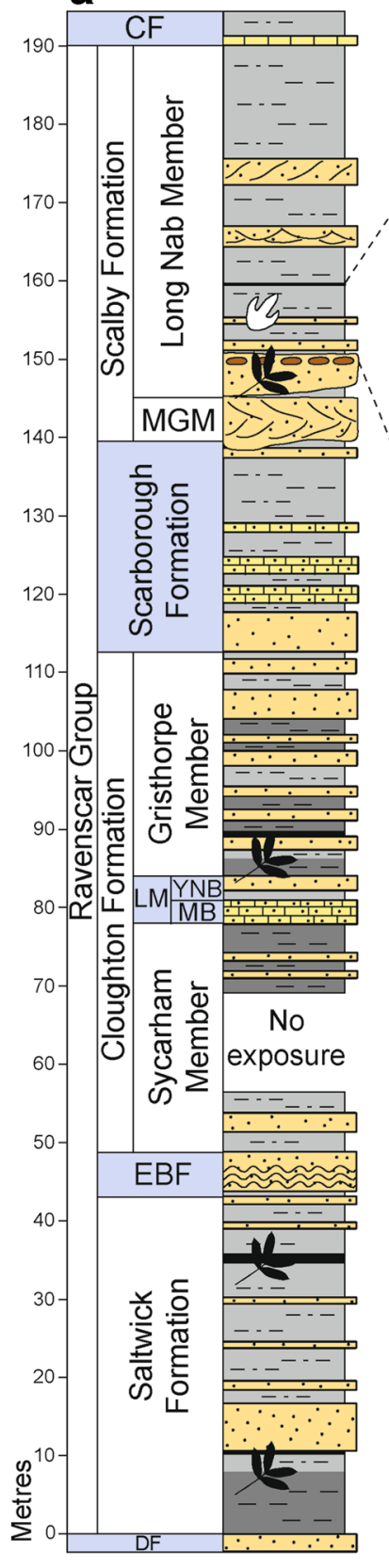

b

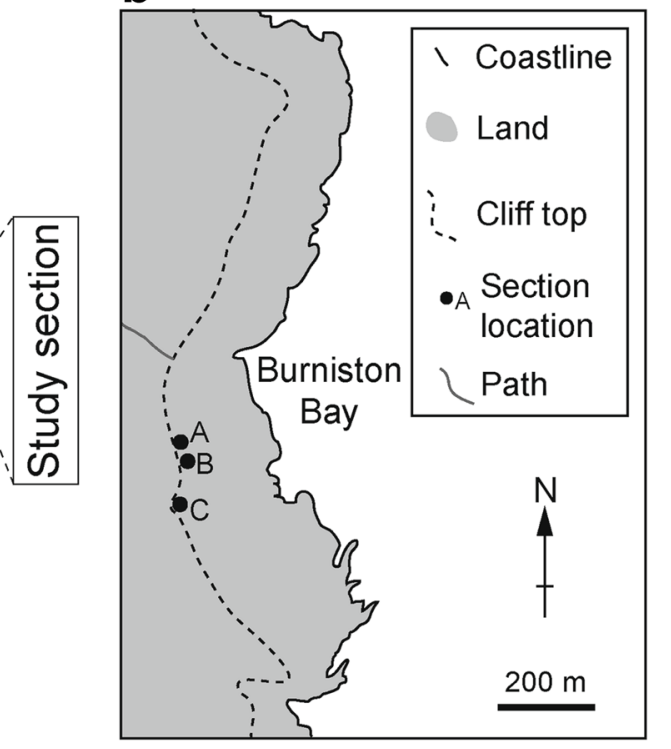

\section{.}
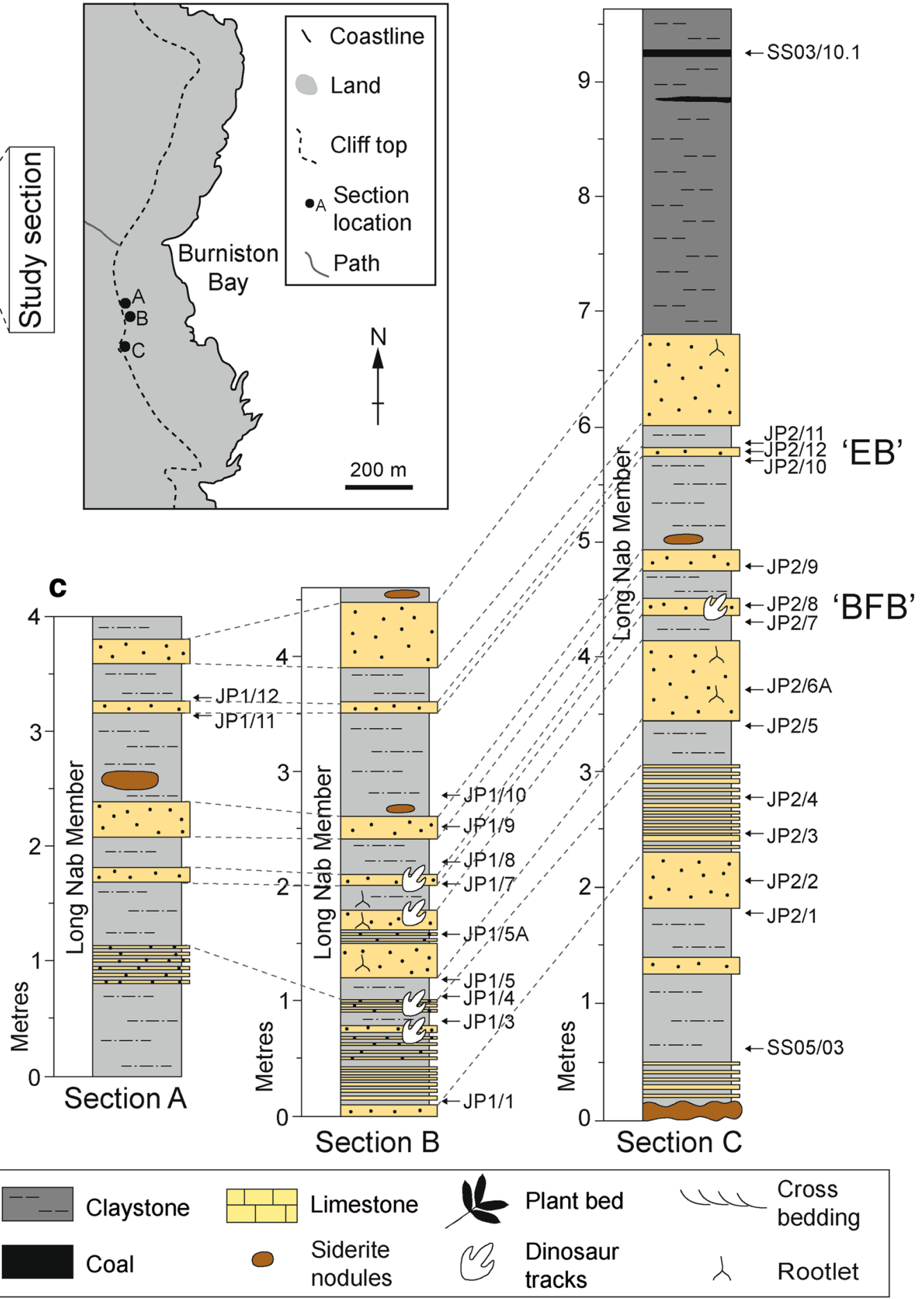

Fig. 2 Sedimentary logs and detailed location of the study section. a Composite sedimentary log of the Middle Jurassic of Yorkshire with the stratigraphic position of the study section. Shaded units represent marine successions. CF Cornbrash Formation, DF Dogger Formation, EBF Eller

Hancock 1985; Riding and Wright 1989) and is sub-divided into the Moor Grit and Long Nab members. The Moor Grit Member comprises coarse channel sandstones, which are overlain by finer-grained sandstones, siltstones and
Beck Formation, LM Lebberston Member, MB Millepore Bed, MGM Moor Grit Member, YNB Yons Nab Beds. b Map showing locations of the studied sections. c Sedimentary logs of studied sections with sample horizons. 'BFB' 'Burniston footprint bed', 'EB' 'event bed'

mudstones of the Long Nab Member. The Long Nab Member at Burniston Bay represents localised channel sediments, and also includes an exceptionally preserved meander plain (Ielpi and Ghinassi 2014) that accumulated in a coastal 

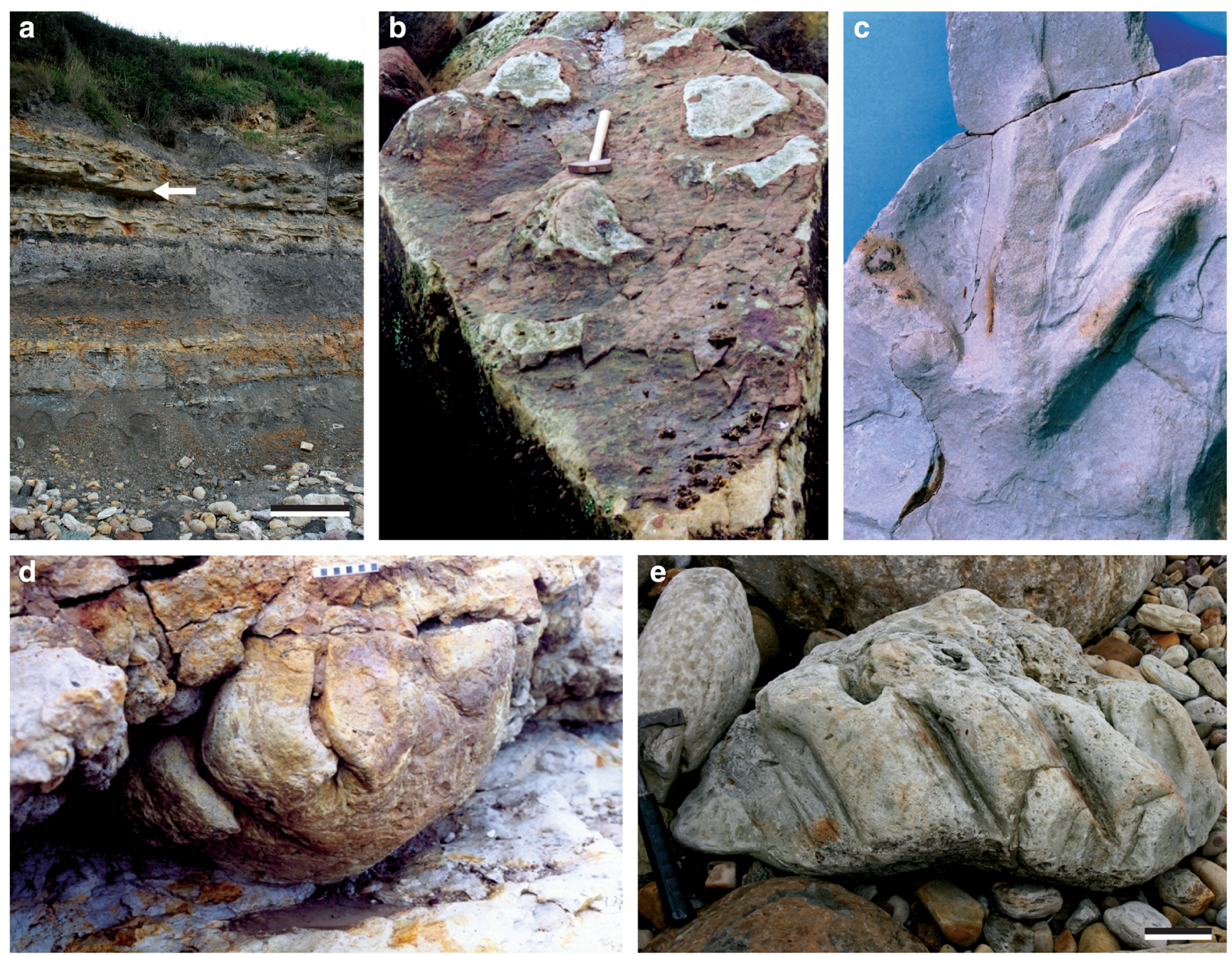

Fig. 3 The 'Burniston footprint bed' with examples of dinosaur tracks from the Jurassic of Yorkshire. a Sedimentary successions from Burniston Bay; arrow marks the 'Burniston footprint bed'. Scale bar $=50 \mathrm{~cm}$. b Deltapodus brodricki trackway from the Saltwick Formation, Whitby, Yorkshire; note the hind foot (pes) and fore foot (manus) impressions (stegosaur maker) (Whyte and Romano 1993; Romano and Whyte 2015). Hammer is $37 \mathrm{~cm}$ long. $\mathbf{c}$ Imprint of a three toed-hind foot of a bipedal dinosaur; note the claw marks at the front of the digit impressions, the pads along the digits and the lack of a clearly defined heel, from the Scalby Formation, Scarborough (Romano and

plain setting (Nami and Leeder 1978; Hancock and Fisher 1981; Livera and Leeder 1981; Fisher and Hancock 1985).

An erosive boundary is present between the Scarborough and Scalby formations (Eschard et al. 1991); based on sedimentological and palynological evidence, several authors have concluded different interpretations for the time-gap represented. One hypothesis suggests a large time gap spanning the lower and middle part of the Bathonian (Leeder and Nami 1979; Hogg 1993), whilst other authors (e.g. Fisher and Hancock 1985; Riding and Wright 1989) consider the time gap to be less extensive (reviewed in Riding and Wright 1989).
Whyte 2003). Print is $14 \mathrm{~cm}$ long. d Hind foot (pes) print of a sauropod dinosaur, showing the subvertical grooves made by the digits on entering, or leaving, the substrate, from the Scalby Formation, Scarborough. Note foot but is the result of preservation in the substrate (Romano and Whyte 2003). Scale bar $=10 \mathrm{~cm}$. e Hind foot (pes) print of a sauropod dinosaur, showing the subvertical grooves made by the digits on entering, or leaving the substrate, from the Scalby Formation, Burniston Bay. Scale bar $=10 \mathrm{~cm}$

Seventeen dinosaur print morphotypes were recognised from this part of the sequence by Romano and Whyte (2003); subsequently, an additional morphotype was described from the northern part of Burniston Bay (Whyte et al. 2006). This latter example was from a bed considered to be the lateral equivalent of the 'Burniston footprint bed'. The readily accessible exposures of the 'Burniston footprint bed' (Fig. 3a), in the middle of Burniston Bay, is undoubtedly a factor in the high density and diversity of dinosaur prints recorded from this part of the Ravenscar Group. However, since Hargreaves $(1913,1914)$ first recorded this unit, there has been no detailed study of the

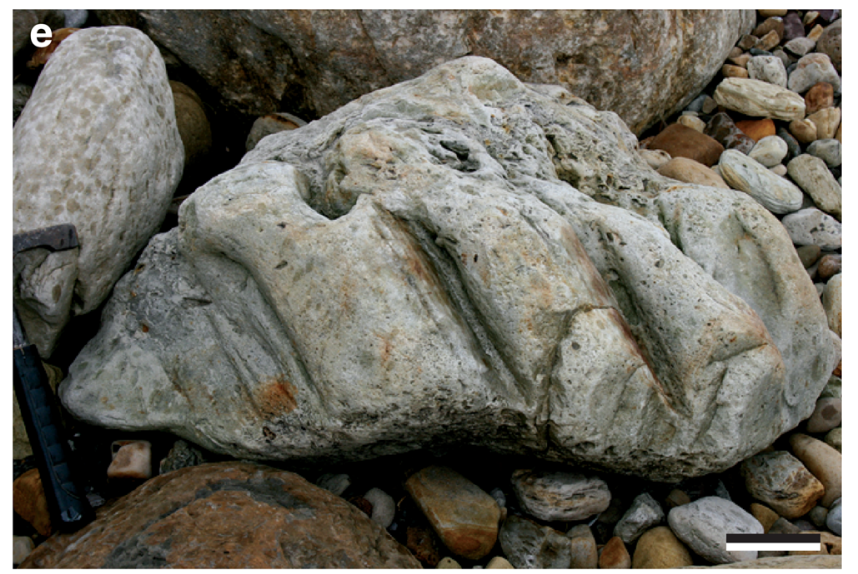
that the bulge at the base of the print does not represent the shape of the 
sedimentology or occurrence of dinosaur prints within the 'footprint bed'. Dinosaur prints occur most commonly at the base of the lowest sandstone of this unit, but are also present towards the top of this $60 \mathrm{~cm}$ thick sandstone package in the middle of Burniston Bay. Further south, the package changes in character, with a higher proportion of mudrock, but dinosaur prints (normally only recognisable in section) still occur within the unit.

\section{Material and methods}

Twenty-five rock samples were collected from three cliff sections (A-C) from Burniston Bay (Figs. 2 and 3). Samples represent c. $1-5 \mathrm{~cm}$ in vertical section from distinct beds. Samples JP1/7 (Fig. 2c, section B) and JP2/8 (Fig. 2c, section C) were collected from the 'Burniston footprint bed'. Dry rock samples (20 g per sample) were dissolved in $40 \%$ $\mathrm{HCl}$ for at least $24 \mathrm{~h}$, followed by 2 weeks in $40 \% \mathrm{HF}$. After sieving, centrifuging residues in zinc chloride was undertaken to remove heavy minerals. Sample processing details are provided in Supplementary Table 1. Residues were then sieved again to remove the heavy liquid, and final residues were spread across cover slips and gently heated to remove excess water. Cover slips were mounted onto slides using epoxy resin. Counts of a minimum of 200 spores and pollen were conducted in systematic traverses across the slides, after which the remainder of each slide was examined to identify taxa that were present in samples but not in counts. To reconstruct vegetation, we follow previous studies (e.g. Balme 1995) in linking spores and pollen to botanical groups.

Excess residues of slides that yielded megaspores were sieved at $100 \mu \mathrm{m}$, and specimens were picked using a fine paint brush and mounted onto SEM stubs. Specimens were gold coated using an Edwards Coater 5250B for 3 min and examined under a Philips XL20 field emission SEM at $15 \mathrm{kV}$. All materials (rock samples and slides) are housed in the collections of the Centre for Palynology at the University of Sheffield, UK.

\section{Results}

The Burniston Bay succession

Well-preserved spore and pollen assemblages (Figs. 4 and 5) of relatively high diversity in association with plant cuticle fragments (Fig. 4j) were recovered throughout the Burniston section. A total of 70 ( 45 spore and 25 pollen) taxa were identified. The commonly used Chao2 species richness estimator (with bias correction) (e.g. Gotelli and Colwell 2001) gave a species estimate of 72.4 (standard deviation of 3.05) for the whole dataset, indicating that the assemblages were wellsampled. Raw spore and pollen count data is provided in
Supplementary Table 2. Abundance changes of selected spores and pollen and botanical groups are provided in Fig. 6 .

Fern spores comprise $\sim 58 \%$ of the total assemblage (ranging between 24 and 91\%) and are consistently dominated by Deltoidospora spp. (47\%) with low abundances of Dictyophyllidites harrisii (4.5\%). Lycophyte spores are low in abundance $(4 \%)$ and bryophyte spores are rare $(0.1 \%)$. Seed ferns represented by Alisporites spp. are moderately abundant $(10 \%)$. The seed fern Caytoniales is represented by the small bisaccate pollen Vitreisporites pallidus, and the presence of Caytoniales in the Yorkshire Jurassic ecosystem is corroborated by the occurrence of macrofossils from the world-famous plant beds scattered throughout the Ravenscar Group (e.g. Hasty Bank and Gristhorpe plant beds; see van Konijnenburg-van Cittert and Morgans 1999). Conifer pollen comprises $\sim 26 \%$ of the total assemblage and is dominated by Araucariacites australis (8.3\%), Perinopollenites elatoides (6.6\%) and Classopollis spp. (3.8\%), with additional bisaccate pollen taxa (5.4\%). Monosulcate pollen (Chasmatosporites spp. [0.5\%] and Cycadopites spp. [1.1\%]) comprises a small portion of the assemblage. Abundances through the section are relatively consistent between samples, suggesting that the vegetation was reasonably stable through the studied interval; this is not particularly surprising considering the section is rather short and probably represents a relatively restricted time interval. Cuticle fragments recovered here are typically more abundant and larger than in samples from the Aalenian and Bajocian of the Yorkshire Jurassic (Slater and Wellman 2016a). This potentially indicates shorter/lower energy transportation distances in the Bathonian part of the succession as delicate cuticle would likely be damaged or destroyed during long-distance/highenergy transportation; alternatively, larger leaf fragments may have been transported and subsequently degraded to cuticle post-burial.

Megaspores were recovered from several samples; Paxillitriletes phyllicus (Fig. 5a, b) was recorded throughout the section within samples JP2/6A, JP2/5, JP2/4, JP2/3 and JP2/2, and Reticuspinosporites whytei (Fig. 5c) was recorded from a single sample, JP2/12, collected from a bed known informally as the 'event bed' (Fig. 2c, section C). This is a 40-145 mm thick bed that can be traced laterally for at least $165 \mathrm{~m}$ in Burniston Bay and probably represents a confined crevasse splay into a shallow water interdistributary bay setting (Romano and Whyte, pers. comm.).

The 'Burniston footprint bed'

Samples from the 'Burniston footprint bed' (JP2/8 and JP1/7; Fig. 7) are dominated by fern spores (75\% [average of samples JP2/8 and JP1/7]), the vast majority of which are Deltoidospora spp. (61.2\% of the total composition), with 

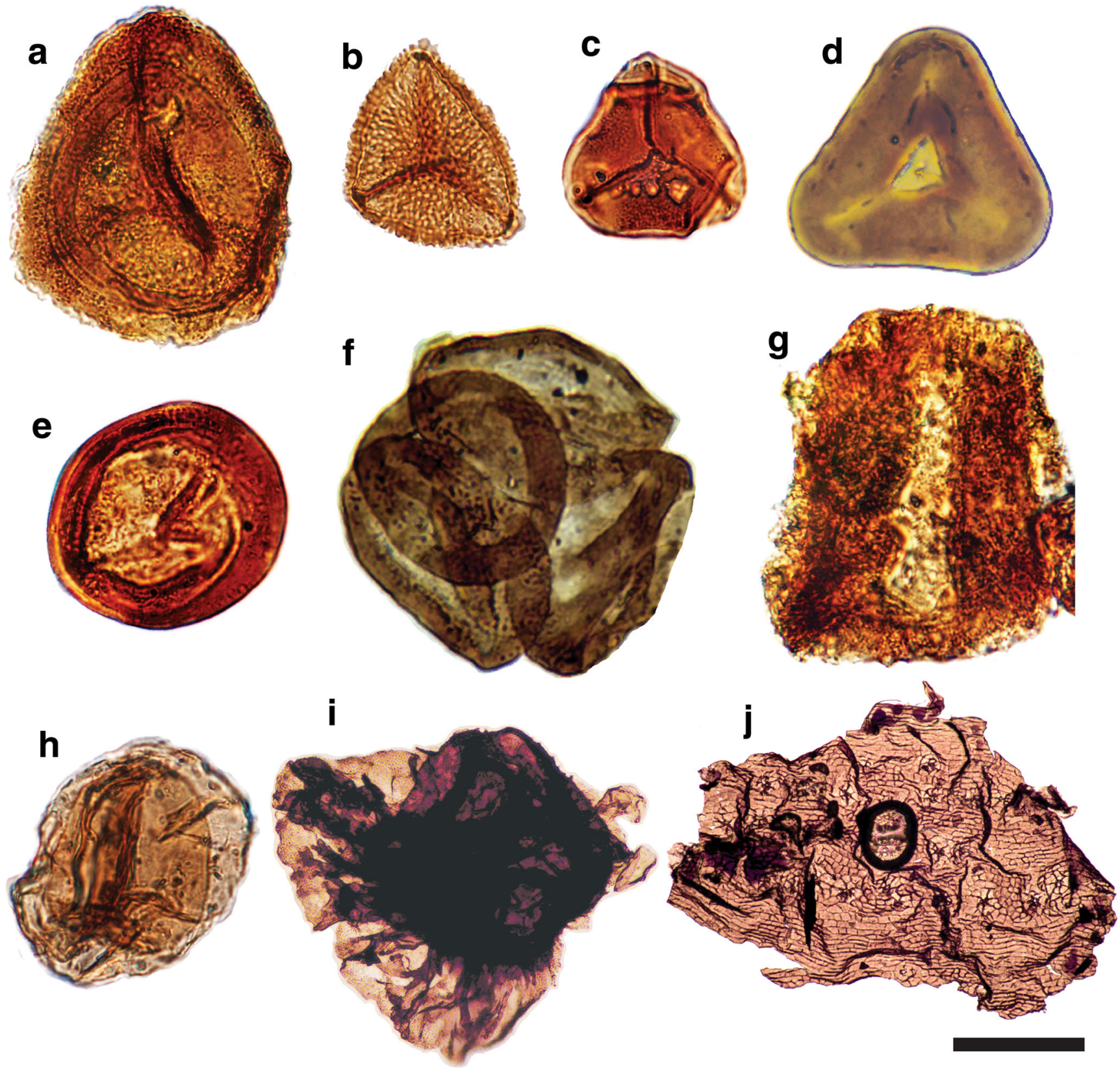

Fig. 4 Light microscope images of selected spores and pollen. a Densoisporites velatus, slide JP1/5i (England finder C40/2). b Sestrosporites pseudoalveolatus, slide JP2/6Aii (England finder F49/2). c Cibotiumspora jurienensis, slide JP1/5i (England finder Q50/2). d Deltoidospora minor, slide JP1/7i (England finder G37/4). e Classopollis spp., slide JP2/3i (England finder U43/1). f Classopollis

low abundances of lycophyte spores (2.8\%). Conifer pollen comprises $13 \%$ of the total composition of the 'Burniston footprint bed' and is dominated by Araucariacites australis (4\% of the total composition). Interestingly, Cerebropollenites mesozoicus peaks in abundance in sample JP2/8 where it comprises $6.2 \%$ of the sample. The probable seed fern pollen Alisporites spp. records high abundances, comprising 6 and spp. tetrad, slide JP2/11ii (England finder B41/C). g Quadraeculina anellaeformis, slide JP1/3i (England finder F39/4). h Perinopollenites elatoides, slide JP2/3ii (England finder W39/1). i Paxillitriletes phyllicus, slide JP2/3ii (England finder G24/3). j Cuticle fragment, sample JP1/10iv (England finder Q39/2). Scale bar $=20 \mu \mathrm{m}$ for $\mathbf{a}-\mathbf{h}$ and $100 \mu \mathrm{m}$ for $\mathbf{i}$ and $\mathbf{j}$

9.5\% of the assemblage in samples JP1/7 and JP2/8, respectively. Abundances of Perinopollenites elatoides (1.4\% [average for samples JP2/8 and JP1/7]), Classopollis spp. (0.5\%), Spheripollenites spp. (0.5\%) and Callialasporites spp. (0.2\%) are low. Monosulcate pollen producers, represented by Cycadopites spp. and Chasmatosporites spp., comprise a small component $(1.4 \%)$ of the assemblage. 

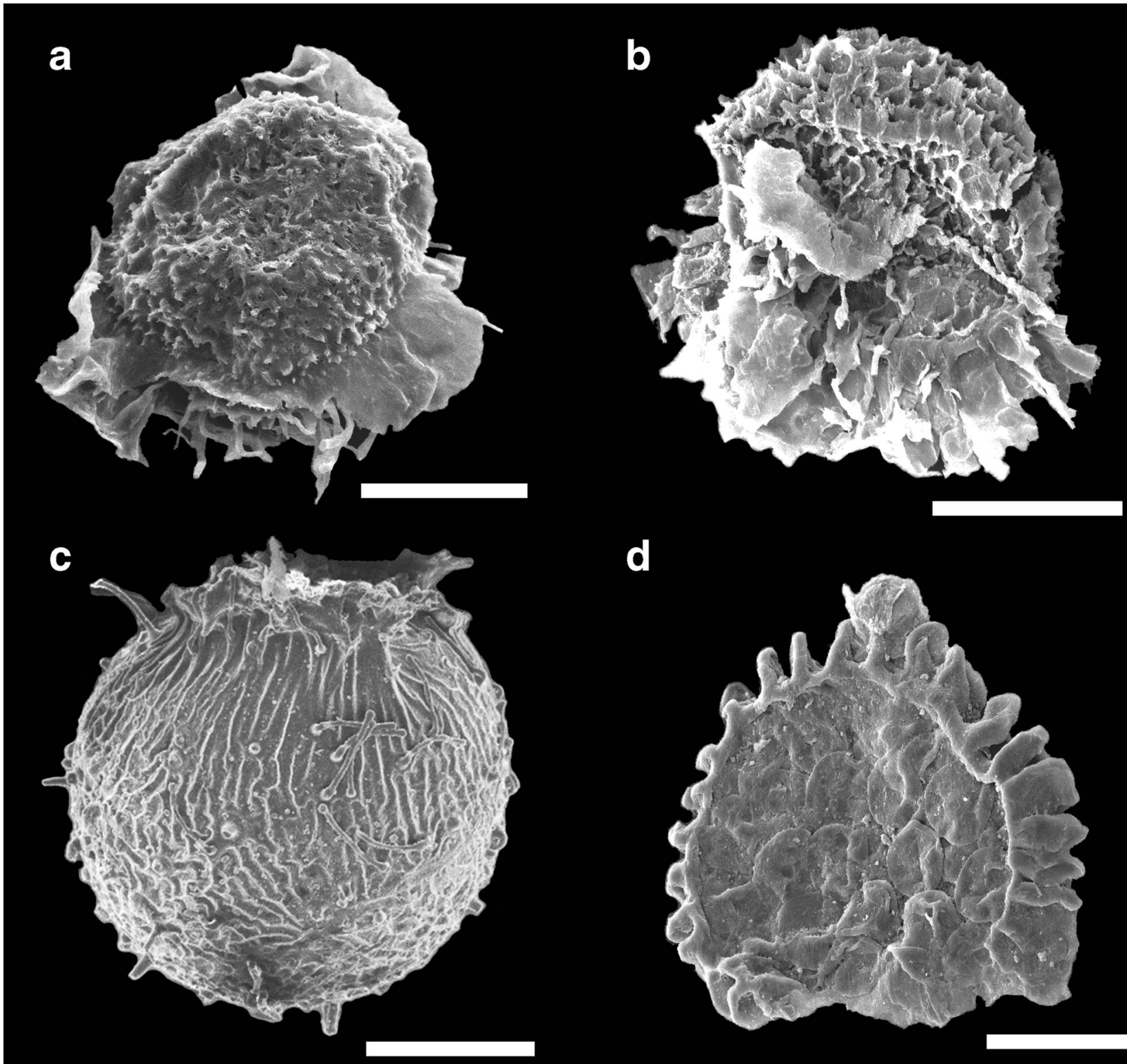

d

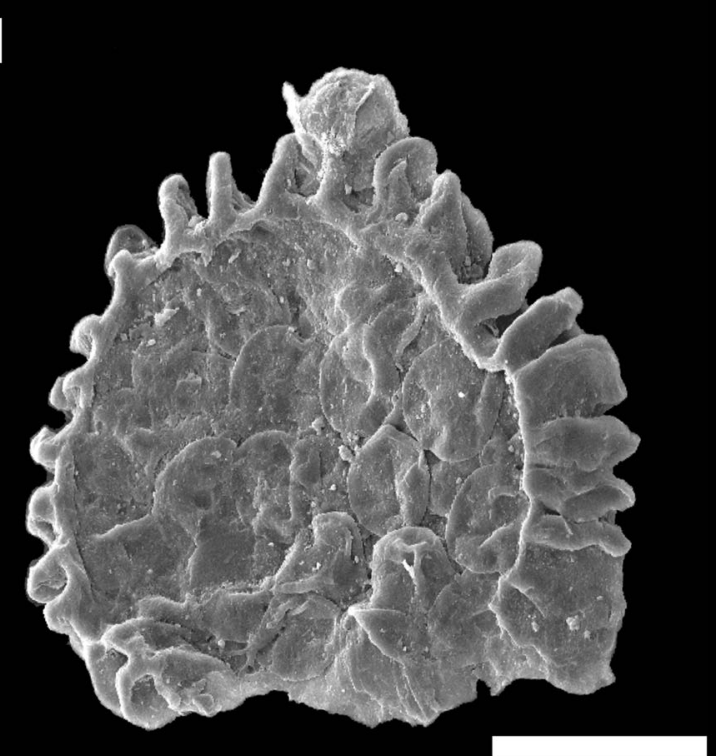

Fig. 5 Scanning electron microscope images of selected megaspores and a fern sporangium. a, b Paxillitriletes phyllicus: a sample JP2/3, b sample JP2/ 4. c Reticuspinosporites whytei, sample JP2/12. d Fern sporangium, sample JP2/2 (Slater and Wellman 2016a). All scale bars $=100 \mu \mathrm{m}$

\section{Discussion and conclusions}

\section{Floral reconstruction}

Reconstructions of the Yorkshire Jurassic flora are primarily based on the extensively studied plant macrofossil beds (see van Konijnenburg-van Cittert and Morgans 1999), which indicate a heterogeneous flora of abundant sphenopsids, ferns, seed ferns, Caytoniales, cycadophytes, ginkgophytes, Czekanowskiales, bennettites and conifers (e.g. Spicer and Hill 1979). The Scalby Ness Plant Bed, which occurs within the same member as the Burniston succession (the Long Nab Member), has yielded $\sim 50$ plant taxa, but particularly abundant are the leaves of Ginkgo huttonii (Ginkgo huttonii pollen is comparable to the dispersed taxa, Cycadopites minimus; Van Konijnenburg-van Cittert 1971; van Konijnenburg-van Cittert and Morgans 1999). Other common components include Coniopteris bella (fern); Otozamites graphicus (Bennettitales); Czekanowskia blackii (Czekanowskiales) and the conifers Brachyphyllum mamillare, Cyparissidium blackii and Pityocladus scarburgensis (van Konijnenburg-van Cittert and Morgans 1999). In the palynoflora, the monosulcate pollen probably represents mostly the ginkgophytes and bennettites, 


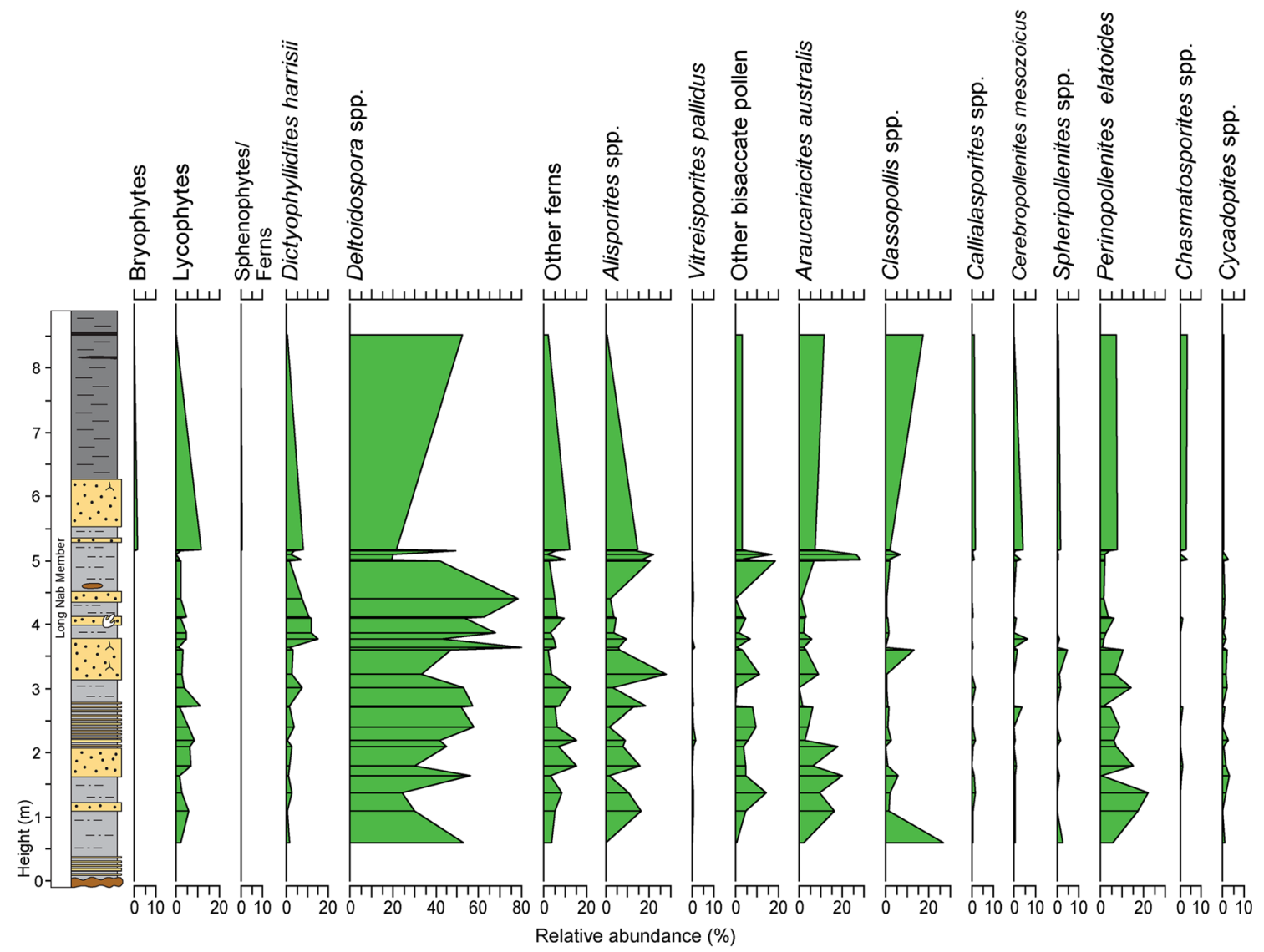

Fig. 6 Relative abundance (percentage) chart of botanical groups and selected spore-pollen taxa from all samples

and Araucariacites australis was probably produced by Brachyphyllum mamillare (van Konijnenburg-van Cittert 1971).

It is typically difficult to assign specific producers to Deltoidospora spp. as this genus has broad botanical affinities (e.g. Balme 1995). However, the occurrence of the ferns Coniopteris bella and Coniopteris hymenophylloides (both of which produce spores comparable to Cyathidites/Deltoidospora spp. [van Konijnenburg-van Cittert 1989; Balme 1995]) in the Scalby Ness plant bed (van Konijnenburg-van Cittert and
Morgans 1999) tentatively suggests that the majority of Deltoidospora spp. recorded here were produced by Coniopteris parent plants.

The spore-pollen data preserves a more complete record of bryophytes and lycophytes - despite extensive collection of plant macrofossils from the Yorkshire Jurassic, no moss-like plants have been recorded from the plant beds (van Konijnenburg-van Cittert and Morgans 1999); liverworts and lycophytes have been described, but are rare (Harris 1961; Thomas 2017). Bryophyte and lycophyte spores are,
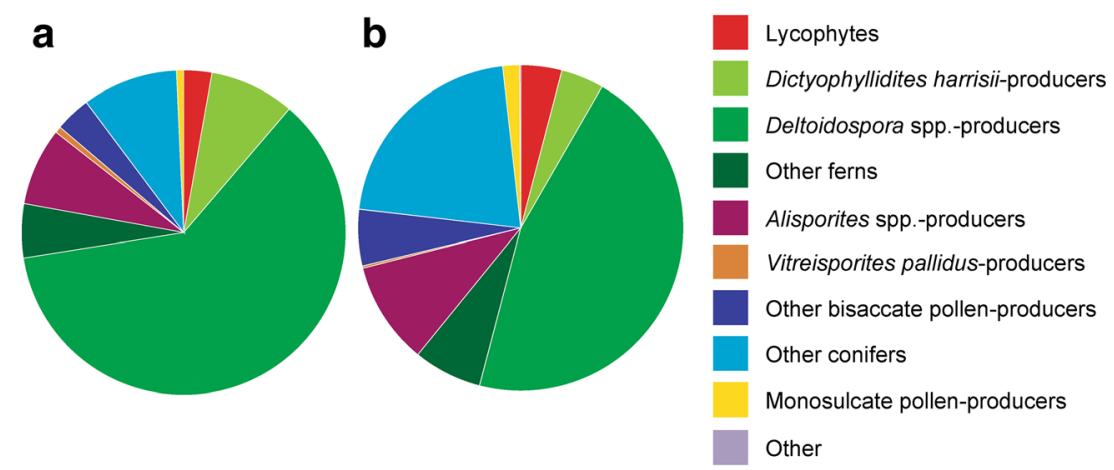

Fig. 7 Pie charts comparing the spore-pollen assemblages of the 'Burniston footprint bed' with all other samples studied here. a Relative abundances (average percentages) of botanical groups and selected

spores/pollen from samples from the 'Burniston footprint bed' (JP2/8 and JP1/7). b Relative abundances (average percentages) of botanical groups and selected spores/pollen from all other samples 


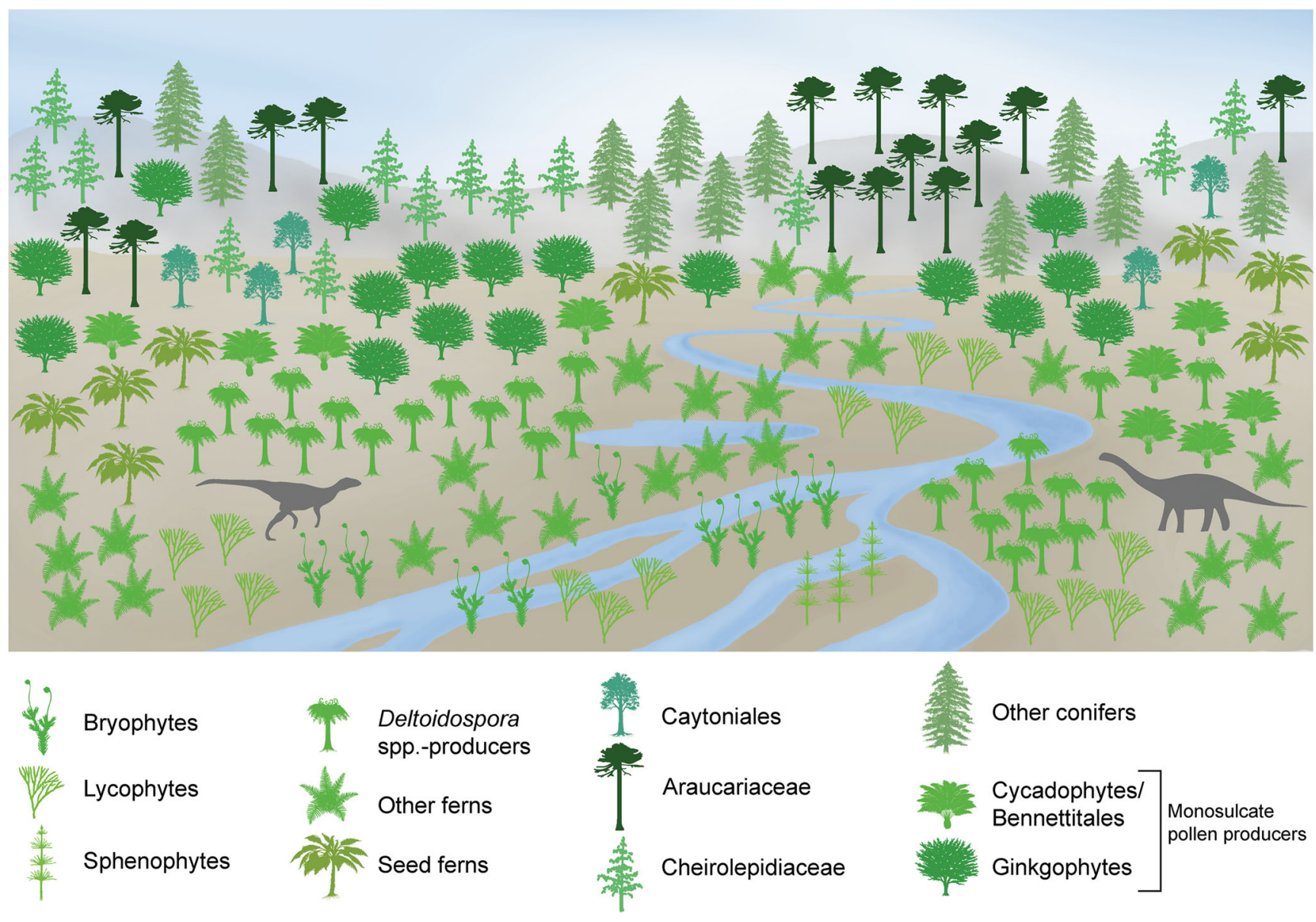

Fig. 8 Environmental reconstruction. Plant groups and distributions are based on spore-pollen assemblages

however, relatively diverse and are recovered throughout the Ravenscar Group (Slater and Wellman 2016a). Megaspores are also relatively common (e.g. Morris and Batten 2016) and most, if not all of the megaspores described from the Yorkshire Middle Jurassic originate from lycopsids. Their relatively high diversity (summarised in Slater et al. 2015) in association with lycophyte microspores indicate that lycophytes were more abundant and diverse than the macrofossil record would suggest. An explanation for the poor representation of lycophytes in the macroflora, also recognised from broadly coeval deposits elsewhere (e.g. Neri et al. 2018, this issue), is that the parent plants were possibly small herbaceous forms, some of which may have been epiphytic, and thus preservation potential would presumably be extremely low. Furthermore, a lack of recognition of delicate lycophyte remains in the Yorkshire Jurassic has contributed to their low representation in the macrofossil record (Skog and Hill 1992; Slater and Wellman 2015).

The spore-pollen assemblages of Burniston Bay differ from the older Aalenian and Bajocian parts of the Yorkshire Jurassic in containing higher abundances of lycophyte spores, fern spores and Alisporites spp., and lower abundances of monosulcate and conifer pollen, especially Classopollis spp., produced by Cheirolepidiaceae (Balme 1995), and Perinopollenites elatoides, produced by Cupressaceae (Balme 1995; Slater and Wellman 2016a). The Burniston assemblages compare well with the 'fern prairies' described by Boulter and Windle (1993) based on spore-pollen data from Bathonian deposits of Oxfordshire, Northamptonshire and Yorkshire. The palynology of the Burniston succession is also similar to Middle Jurassic spore-pollen assemblages from the UK North Sea (Slater et al. 2017), Scandinavia (Tralau 1967, 1968; Tralau and Artursson 1972; Gry 1969; Guy-Ohlson 1971, 1978, 1986, 1989; Mehlqvist et al. 2009; Vajda 2001; Vajda and Wigforss-Lange 2009) and Ukraine (Shevchuk et al. 2018, this issue), revealing extensive, relatively homogenous vegetation extending across Europe at this time.

\section{Dinosaur palaeoecology}

The dinosaurs of the Yorkshire Jurassic, many of them herbivores, probably gathered at the flood plains of the Cleveland Basin to gain access to fresh-water and also used the nonvegetated plains and coastline (cf. Diedrich 2011) as pathways. The diverse vegetation and low-lying land of the Cleveland Basin (Fig. 8) presumably represented an attractive 
and easily accessible food source for the dinosaurs. Whilst at present it has generally not proved possible to assign specific makers to the footprints, it is clear that a range of theropod (large and small), ornithopod (large and small gracile) and sauropod dinosaurs inhabited the area during the Middle Jurassic; in particular, a top theropod predator may tentatively be assigned to Megalosaurus (Whyte et al. 2006).

The topic of dinosaur herbivory has received much attention in recent years (e.g. Sander et al. 2010; Gee 2011; Sander et al. 2011; Clauss et al. 2013; Barrett 2014). Direct evidence of diets (e.g. 'stomach' contents) is rare in the fossil record; however, assessing diets through the study of coprolites has revealed valuable information concerning the habitat in which the animals lived (Scott et al. 2003; Vajda et al. 2016). High phosphate content (originating from undigested skeletal matter) and the presence of bone fragments in coprolites characterise carnivores, and these tend to fossilise to a greater extent (Chin 2002). Interestingly, enhanced preservation of palynomorphs within coprolites compared to host-rocks has been noted and attributed to rapid burial and encasement in calcium phosphate preventing degradation of sporopollenin (Vajda et al. 2016). Caution should, however, be taken when referring pollen and cuticle contents of coprolites to diets as particles tend to attach to faecal matter when moist (Andrews and Fernández-Jalvo 1998), and further, fungi often develop on faeces, which can falsely suggest a fungal diet (Sander et al. 2010).

Several examples of coprolites have been recorded from the Yorkshire Jurassic. Hill (1976) described a cluster of c. 250 coprolite pellets from the Saltwick Formation, each measuring 8-18 $\mathrm{mm}$ in diameter, which are considered to be dinosaurian in origin (Chin 1997, 2007; Weishampel et al. 2004). Cuticles were recovered from the coprolites comprising > 99\% Ptilophyllum pectinoides (Bennettitales). Harris (1946, 1951, 1956, 1964) and Harris et al. (1974) recorded smaller clusters of smaller pellets from the Jurassic of Yorkshire which were predominantly composed of Caytonia, Solenites, Androstrobus and thin bennettitalean cuticles; however, these were probably not produced by dinosaurs (Whyte et al. 2010).

Based on experiments to evaluate metabolizable energy content of various gymnosperms and spore-producing plants, Hummel et al. (2008) demonstrated that Equisetum, Araucaria, Ginkgo and Angiopteris represented viable food sources for sauropods. These plant genera are frequently recovered from dinosaur-bearing deposits (e.g. Hinz et al. 2010), and Equisetum is abundant in the lower parts of the Ravenscar Group (Spicer and Hill 1979), where dinosaur footprints also occur (Romano and Whyte 2003). In the Burniston succession, abundances of Araucariacites australis are high within conifer pollen assemblages, and the dominance of Ginkgo in the Scalby Ness Plant Bed points towards a possible Araucariaceae and Ginkgo food source. Speculation of dinosaurian diets based on vegetation reconstructions in dinosaur- inhabited regions is, however, tentative, and potential future direct lines of evidence from the Yorkshire Jurassic will assist to test such hypotheses.

Acknowledgements We thank Mike Pole and Evelyn Kustatscher for their constructive reviews which improved this paper. John Poulter was involved in collecting the majority of the rock samples that were processed here. We thank Pollyanna von Knorring for artwork in Fig. 8. This is a contribution to the UNESCO/IGCP project 632, Continental Crises of the Jurassic: Major Extinction Events and Environmental Changes Within Lacustrine Ecosystems.

Funding information This research was funded by a Natural Environment Research Council CASE (NE/J500100) Award with Shell Research Limited and a Swedish Research Council grant, VR 201504264 .

\section{Compliance with ethical standards}

Conflict of interest The authors declare that they have no conflict of interest.

Open Access This article is distributed under the terms of the Creative Commons Attribution 4.0 International License (http:// creativecommons.org/licenses/by/4.0/), which permits unrestricted use, distribution, and reproduction in any medium, provided you give appropriate credit to the original author(s) and the source, provide a link to the Creative Commons license, and indicate if changes were made.

\section{References}

Alexander, J. (1989). Delta or coastal plain? With an example of the controversy from the Middle Jurassic of Yorkshire. In M. K. G. Whateley \& K. T. Pickering, (Eds.), Deltas: sites and traps for fossil fuels (pp. 11-19). Geological Society Special Publications, 41.

Alexander, J. (1992). A discussion of alluvial sandstone body characteristics related to variations in marine influence, Middle Jurassic of the Cleveland Basin, UK, and the implications for analogous Brent Group strata in the North Sea Basin. In A. C. Morton, R. S. Haszeldine, M. R. Giles \& S. Brown, (Eds.), Geology of the Brent Group (pp. 149-167). Geological Society, Special Publications, 61.

Anderson, J. M., Anderson, H. M., \& Cleal, C. J. (2007). Brief history of the gymnosperms: classification, biodiversity, phytogeography and ecology. Sterlitzia, volume 20. Pretoria: National Botanic Institute.

Andrews, P., \& Fernández-Jalvo, Y. (1998). 101 uses for fossilized faeces. Nature, 393, 629-630.

Balme, B. E. (1995). Fossil in situ spores and pollen grains: an annotated catalogue. Review of Palaeobotany \& Palynology, 87, 81-323.

Barrett, P. M. (2014). Paleobiology of herbivorous dinosaurs. Annual Review of Earth and Planetary Sciences, 42, 207-230.

Boulter, M., \& Windle, T. (1993). A reconstruction of some Middle Jurassic vegetation in northern Europe. Special Papers in Palaeontology, 49, 125-154.

Brodrick, H. (1907). A find!! Report of the Whitby Literary and Philosophical Society, 85, 8-9.

Chaloner, W. G. (1968). The palaeoecology of fossil spores. In E. T. Drake (Ed.), Evolution and environment (pp. 125-138). New Haven: Yale University Press.

Chaloner, W. G., \& Muir, M. (1968). Spores and floras. In D. Murchison \& T. S. Westoll (Eds.), Coal and coal-bearing strata (pp. 127-146). Edinburgh: Oliver and Boyd. 
Chin, K. (1997). What did dinosaurs eat? Coprolites and other direct evidence of dinosaur diets. In J. O. Farlow \& M. K. Brett-Surman (Eds.), The complete dinosaur (pp. 264-290). Bloomington: Indiana University Press.

Chin, K. (2002). Analyses of coprolites produced by carnivorous vertebrates. The Paleontological Society Papers, 8, 43-50.

Chin, K. (2007). The paleobiological implications of herbivorous dinosaur coprolites from the Upper Cretaceous Two Medicine Formation of Montana: why eat wood? PALAIOS, 22, 554-566.

Clauss, M., Steuer, P., Müller, D. W. H., Cordon, D., \& Hummel, J. (2013). Herbivory and body size: allometries of diet quality and gastrointestinal physiology, and implications for herbivore ecology and dinosaur gigantism. PLoS ONE, 8(10), e68714. https://doi.org/ 10.1371/journal.pone.0068714.

Couper, R. A. (1958). British Mesozoic microspores and pollen grains. Palaeontographica Abteilung B, 103, 75-179.

Diedrich, C. (2011). Upper Jurassic tidal flat megatracksites of Germany-coastal dinosaur migration highways between European islands, and a review of the dinosaur footprints. Palaeobiodiversity and Palaeoenvironments, 91, 129-155.

Eschard, R., Ravenne, C., Houel, P., \& Knox, R. (1991). Threedimensional reservoir architecture of a valley-fill sequence and a deltaic aggradational sequence: Influences of minor relative sealevel variations (Scalby Formation, England). In A. D. Miall \& N. Tyler (Eds.), The three-dimensional facies architecture of terrigenous clastic sediments and its implications for hydrocarbon discovery and recovery (pp. 133-147). Tulsa, Oklahoma: SEPM Society for Sedimentary Geology.

Fisher, M. J., \& Hancock, N. J. (1985). The Scalby Formation (Middle Jurassic, Ravenscar Group) of Yorkshire: reassessment of age and depositional environment. Proceedings of the Yorkshire Geological Society, 45, 293-298.

Gee, C. (2011). Dietary options for the sauropod dinosaurs from an integrated botanical and paleobotanical perspective. In N. Klein, K. Remes, C. T. Gee, \& P. M. Sander (Eds.), Biology of the sauropod dinosaurs: Understanding the life of giants (pp. 34-56). Bloomington: Indiana University Press.

Gotelli, N. J., \& Colwell, R. K. (2001). Quantifying biodiversity: procedures and pitfalls in the measurement and comparison of species richness. Ecological Letters, 4, 379-391.

Gry, H. (1969). Megaspores from the Jurassic of the island of Bornholm, Denmark. Meddelelser fra Dansk Geologisk Førening, 19, 69-89.

Guy-Ohlson, D. (1971). Palynological investigations in the Middle Jurassic of the Vilhelmsfält boring, southern Sweden. Publications from the Institutes of Mineralogy, Palaeontology and Quaternary Geology, University of Lund, 168, 1-104.

Guy-Ohlson, D. (1978). Jurassic biostratigraphy of three borings in NW Scania-a brief palynological report. Sveriges Geologiska Undersökning. Rapporter och Meddelanden, 11, 1-41.

Guy-Ohlson, D. (1986). Jurassic palynology of the Vilhelmsfält Bore No. 1, Scania, Sweden. Toarcian-Aalenian. Stockholm: Section of Palaeobotany, Swedish Museum of Natural History.

Guy-Ohlson, D. (1989). Spore and pollen assemblage zonation of Swedish Bajocian and Bathonian sediments. In D. J. Batten \& M. C. Keen (Eds.), Northwest European micropalaeontology and palynology (pp. 70-91). London: British Micropalaeontological Society.

Hancock, N. J., \& Fisher, M. J. (1981). Middle Jurassic North Sea deltas with particular reference to Yorkshire. In L. V. Illing \& G. D. Hobson (Eds.), Petroleum geology of the continental shelf of north-west Europe (pp. 186-195). London: Institute of Petroleum.

Hargreaves, J. A. (1913). Fossil footprints near Scarborough. The Naturalist, 1913, 92-95.

Hargreaves, J. A. (1914). Fossil footprints near Scarborough. The Naturalist, 1914, 154-156.
Harris, T. M. (1946). Notes on the Jurassic flora of Yorkshire. Annals and Magazine of Natural History: Series 11, 12, 357-378.

Harris, T. M. (1951). Notes on the Jurassic flora of Yorkshire. Annals and Magazine of Natural History: Series 12, 4, 915-937.

Harris, T. M. (1956). The investigation of a fossil plant. Proceedings of the Royal Institution of Great Britain, 36, 1-11.

Harris, T. M. (1961). The Yorkshire Jurassic flora I. ThallophytaPteridophyta. London: British Museum (Natural History).

Harris, T. M. (1964). The Yorkshire Jurassic flora II. Caytoniales, Cycadales and pteridosperms. London: British Museum (Natural History).

Harris, T. M. (1969). The Yorkshire Jurassic flora III. Bennettitales. London: British Museum (Natural History).

Harris, T. M. (1979). The Yorkshire Jurassic flora V. Coniferales. London: British Museum (Natural History).

Harris, T. M., Millington, W., \& Miller, J. (1974). The Yorkshire Jurassic flora IV. Ginkgoales and Czekanowskiales. London: British Museum (Natural History).

Hemingway, J. E., \& Knox, R. W. O’B. (1973). Lithostratigraphical nomenclature of the Middle Jurassic strata of the Yorkshire Basin of north-east England. Proceedings of the Yorkshire Geological Society, 39, 527-535.

Hill, C. R. (1976). Coprolites of Ptilophyllum cuticles from the Middle Jurassic of North Yorkshire. Bulletin of the British Museum (Natural History), Geology, 27, 289-293.

Hinz, J. K., Smith, I., Pfretzschner, H.-U., Wings, O., \& Sun, G. (2010). A high-resolution three-dimensional reconstruction of a fossil forest (Upper Jurassic Shishugou Formation, Junggar Basin, Northwest China). Palaeobiodiversity and Palaeoenvironments, 90, 215-240.

Hogg, N. M. (1993). A palynological investigation of the Scalby Formation (Ravenscar Group, Middle Jurassic) and adjacent strata from the Cleveland Basin, north-east Yorkshire. Unpublished PhD thesis, University of Sheffield.

Hummel, J., Gee, C. T., Südekum, K.-H., Sander, P. M., Nogge, G., \& Clauss, M. (2008). In vitro digestibility of fern and gymnosperm foliage: implications for sauropod feeding ecology and diet selection. Proceedings of the Royal Society of London B 275, 1015-1021.

Ielpi, A., \& Ghinassi, M. (2014). Planform architecture, stratigraphic signature and morphodynamics of an exhumed Jurassic meander plain (Scalby Formation, Yorkshire, UK). Sedimentology, 61, 1923-1960.

Knox, R. W. O'B. (1973). The Eller Beck Formation (Bajocian) of the Ravenscar Group of NE Yorkshire. Geological Magazine, 110, 511534.

Leeder, M. R., \& Nami, M. (1979). Sedimentary models for the nonmarine Scalby Formation (Middle Jurassic) and evidence for late Bajocian/Bathonian uplift of the Yorkshire Basin. Proceedings of the Yorkshire Geological Society, 42, 461-482.

Livera, S. E., \& Leeder, M. R. (1981). The Middle Jurassic Ravenscar Group ('Deltaic Series') of Yorkshire: recent sedimentological studies as demonstrated during a field meeting 2-3 May 1980. Proceedings of the Geologists' Association, 92, 241-250.

Manning, P. L., Egerton, V. M., \& Romano, M. (2015). A new sauropod dinosaur from the Middle Jurassic of the United Kingdom. PLoS ONE, 10(6), e0128107. https://doi.org/10.1371/journal.pone. 0128107

Mehlqvist, K., Vajda, V., \& Larsson, L. (2009). An assemblage of a Middle Jurassic flora from Bornholm, Denmark - a study of a historic collection at Lund University, Sweden. GFF, 131, 137-146.

Milsom, J., \& Rawson, P. F. (1989). The peak trough — a major control on the geology of the North Yorkshire coast. Geological Magazine, 126, 699-705.

Mjøs, R., \& Prestholm, E. (1993). The geometry and organization of fluviodeltaic channel sandstones in the Jurassic Saltwick Formation, Yorkshire, England. Sedimentology, 40, 919-935. 
Morris, P. H., \& Batten, D. B. (2016). Megaspores and associated palynofloras of Middle Jurassic fluviodeltaic sequences in North Yorkshire and the northern North Sea: a biofacies-based approach to palaeoenvironmental analysis and modelling. Journal of Micropalaeontology, 35, 151-172.

Nami, M., \& Leeder, M. R. (1978). Changing channel morphology and magnitude in the Scalby Formation (M. Jurassic) of Yorkshire, England. In A. D. Miall (Ed.), Fluvial sedimentology (pp. 431440). Calgary: Canadian society of petroleum geologists memoir 5.

Neri, M., Kustatscher, E., \& Roghi, G. (2018). Megaspores from the Lower Jurassic (Pliensbachian) Rotzo Formation (Monti Lessini, northern Italy) and their paleoenvironmental implications. In S. Slater, E. Kustatscher \& V. Vajda, (Eds.), Jurassic biodiversity and terrestrial environments. Palaeobiodiversity and Palaeoenvironments, 98(1) https://doi.org/10.1007/s12549-017-0314-z.

Palliani, R. B., \& Riding, J. B. (2000). A palynological investigation of the Lower and lowermost Middle Jurassic strata (Sinemurian to Aalenian) from North Yorkshire, UK. Proceedings of the Yorkshire Geological Society, 53, 1-16.

Powell, J. H. (2010). Jurassic sedimentation in the Cleveland Basin: a review. Proceedings of the Yorkshire Geological Society, 58, 21-72.

Prasad, D., Strömberg, C. A. E., Alimohammadian, H., \& Sahni, A. (2005). Dinosaur coprolites and the early evolution of grasses and grazers. Science, 310, 1177-1180.

Rawson, P. F., \& Wright, J. K. (2000). The Yorkshire coast. London: Geologists' Association Guide, 34.

Riding, J. B., \& Wright, J. K. (1989). Palynostratigraphy of the Scalby Formation (Middle Jurassic) of the Cleveland Basin, north-east Yorkshire. Proceedings of the Yorkshire Geological Society, 47, 349-354.

Romano, M., \& Whyte, M. A. (2003). Jurassic dinosaur tracks and trackways of the Cleveland Basin, Yorkshire: preservation, diversity and distribution. Proceedings of the Yorkshire Geological Society, 54, $185-215$.

Romano, M., \& Whyte, M. A. (2015). Could stegosaurs swim? Suggestive evidence from the Middle Jurassic tracksite of the Cleveland Basin, Yorkshire, UK. Proceedings of the Yorkshire Geological Society, 60, 227-233.

Sander, P. M., Gee, C. T., Hummel, J., \& Clauss, M. (2010). Mesozoic plants and dinosaur Herbivory. In C. T. Gee (Ed.), Plants in Mesozoic time: innovations, phylogeny, ecosystems (pp. 331-359). Bloomington: Indiana University Press.

Sander, P. M., Christian, A., Clauss, M., Fechner, R., Gee, C. T., Griebeler, E.-M., Gunga, H.-C., Hummel, J., Mallison, H., Perry, S. F., Preuschoft, H., Rauhut, O. W. M., Remes, K., Tütken, T., Wings, O., \& Witzel, U. (2011). Biology of the sauropod dinosaurs: the evolution of gigantism. Biological Reviews, 86, 117-155.

Scott, L., Fernández-Jalvo, Y., Carrión, J., \& Brink, J. (2003). Preservation and interpretation of pollen in hyaena coprolites: taphonomic observations from Spain and southern Africa. Palaeontologica Africana, 39, 83-91.

Shevchuk, O., Slater, S. M., \& Vajda, V. (2018). Palynology of Jurassic (Bathonian) sediments of Donbas, North East Ukraine. In S. Slater, E. Kustatscher \& V. Vajda, (Eds.), Jurassic biodiversity and terrestrial environments. Palaeobiodiversity and Palaeoenvironments, 98(1). https://doi.org/10.1007/s12549-017-0310-3 [this issue].

Skog, J. E., \& Hill, C. R. (1992). The Mesozoic herbaceous lycopsids. Annals of the Missouri Botanical Garden, 79, 648-675.

Slater, S. M., \& Wellman, C. H. (2015). A quantitative comparison of dispersed spore/pollen and plant megafossil assemblages from a Middle Jurassic plant bed from Yorkshire, UK. Paleobiology, 41, 640-660.

Slater, S. M., \& Wellman, C. H. (2016a). Middle Jurassic vegetation dynamics based on quantitative analysis of spore/pollen assemblages from the Ravenscar Group, North Yorkshire, UK. Palaeontology, 59, 305-328.
Slater, S. M., \& Wellman, C. H. (2016b). Data from: Middle Jurassic vegetation dynamics based on quantitative analysis of spore/pollen assemblages from the Ravenscar Group, North Yorkshire, UK. Dryad Digital Repository. https://doi.org/10.5061/dryad.cc0m7.

Slater, S. M., Taylor, W. A., Batten, D. J., Hill, C. R., \& Wellman, C. H. (2015). Morphology and wall ultrastructure of a new and highly distinctive megaspore from the Middle Jurassic of Yorkshire, UK. Review of Palaeobotany \& Palynology, 216, 33-43.

Slater, S. M., McKie, T., Vieira, M., Wellman, C. H., \& Vajda, V. (2017). Episodic river flooding events revealed by palynological assemblages in Jurassic deposits of the Brent Group, North Sea. Palaeogeography, Palaeoclimatology, Palaeoecology, 485, 389-400.

Slater, S., Kustatscher, E., \& Vajda, V. (2018). An introduction to Jurassic biodiversity and terrestrial environments. In S. Slater, E. Kustatscher \& V. Vajda (Eds.), Jurassic biodiversity and terrestrial environments. Palaeobiodiversity and Palaeoenvironments, 98(1). https:// doi.org/10.1007/s12549-017-0316-x [this issue]

Spicer, R. A., \& Hill, C. R. (1979). Principal components and correspondence analyses of quantitative data from a Jurassic plant bed. Review of Palaeobotany and Palynology, 28, 273-299.

Srivastava, S. K. (2011). Spore-pollen biostratigraphy of the English Jurassic. Palaeontographica Abteilung B, 285, 113-201.

Thomas, B. A. (2017). The occurrence of Lycopodites hannahensis Harris in the Yorkshire Jurassic together with details of its anatomy. Proceedings of the Yorkshire Geological Society. https://doi.org/10. 1144/pygs2017-381.

Tralau, H. (1967). Some Middle Jurassic microspores of southern Sweden. Geologiska Föreningen i Stockholm Förhandlingar, 89, $469-472$.

Tralau, H. (1968). Botanical investigation into the fossil flora of Eriksdal in Fyledalen, Scania. II. The Middle Jurassic microflora. Sveriges Geologiska Undersökning. Serie C, 633, 1-185.

Tralau, H., \& Artursson, K. (1972). New Middle Jurassic pollen and spore floras from southern Sweden and the Öresund. Grana, 12, 57-63.

Upchurch, P., \& Barrett, P. M. (2005). Phylogenetic and taxic perspectives on sauropod diversity. In K. A. Curry-Rogers \& J. A. Wilson (Eds.), The Sauropods: evolution and paleobiology (pp. 104-124). Berkeley: University of California press.

Vajda, V. (2001). Aalenian to Cenomanian palynofloras of SW Scania, Sweden. Acta Paleontologica Polonica, 46, 403-426.

Vajda, V., \& Wigforss-Lange, J. (2009). Onshore Jurassic of Scandinavia and related areas. GFF, 131, 5-23.

Vajda, V., Calner, M., \& Ahlberg, A. (2013a). Palynostratigraphy of dinosaur footprint-bearing deposits from the Triassic-Jurassic boundary interval of Sweden. GFF, 135, 120-130.

Vajda, V., Lyson, T. R., Bercovici, A., Doman, J. A., \& Pearson, D. A. (2013b). A snapshot into the terrestrial ecosystem of an exceptionally well-preserved dinosaur (Hadrosauridae) from the Upper Cretaceous of North Dakota, USA. Cretaceous Research, 46, 114 122.

Vajda, V., Pesquero Fernández, D., Villanueva-Amadoz, U., Lehsten, V., \& Alcalá, L. (2016). Dietary and environmental implications of Early Cretaceous predatory dinosaur coprolites from Teruel, Spain. Palaeogeography, Palaeoclimatology, Palaeoecology, 464, 134 142.

van Konijnenburg-van Cittert, J. H. A. (1971). In situ gymnosperm pollen from the Middle Jurassic of Yorkshire. Acta Botanica Neerlandica, 20, 1-97.

van Konijnenburg-van Cittert, J. H. A. (1989). Dicksoniaceous spores in situ from the Jurassic of Yorkshire, England. Review of Palaeobotany and Palynology, 61, 273-301.

van Konijnenburg-van Cittert, J. H. A., \& Morgans, H. S. (1999). The Jurassic flora of Yorkshire. London: The Palaeontological Association.

Weishampel, D. B., Barrett, P. M., Coria, R. A., Le Loeuff, J., Xu, X., Zhao, X., Sahni, A., Gomani, E. M. P., \& Noto, C. R. (2004). 
Dinosaur distribution. In D. B. Weishampel, P. Dodson, \& H. Osmolska (Eds.), The Dinosauria, second edition (pp. 517-606). Berkeley: University of California Press.

Whyte, M. A., \& Romano, M. (1993). Footprints of a sauropod dinosaur from the Middle Jurassic of Yorkshire. Proceedings of the Geologists' Association, 104, 195-199.

Whyte, M. A., Romano, M., Hudson, J. G., \& Watts, W. (2006). Discovery of the largest theropod dinosaur track known from the Middle Jurassic of Yorkshire. Proceedings of the Yorkshire Geological Society, 56, 77-80.
Whyte, M. A., Romano, M., \& Watts, W. (2010). Yorkshire dinosaurs: a history in two parts. In R. T. J. Moody, E. Buffetaut, D. Naish \& D. M. Martill, (Eds.), Dinosaurs and other extinct saurians: a historical perspective (pp. 189-207). Geological Society, London, Special Publications, 343.

Young, G. M., \& Bird, J. (1822). A geological survey of the Yorkshire coast: describing the strata and fossils occurring between the Humber and the Tees, from the German Ocean to the plain of York. Whitby: R. Kirby. 